Oral Tradition, 1/3 (1986): 504-47

\title{
The Oral Background of Byzantine Popular Poetry
}

\section{Elizabeth and Michael Jeffreys}

The popular poetry of Byzantium first appears in the form of consistent surviving texts of some size in the middle of the twelfth century, at the courts of the emperors John Komnenos (1118-1143) and Manuel Komnenos (1143-1180). ${ }^{1}$ Little or no such poetry seems to survive from the thirteenth century, when Byzantine energies were occupied in the reconquest of Constantinople and other parts of the empire from the forces of the Fourth Crusade. The next preserved examples seem to date from early in the fourteenth century, and the popular poetic tradition then continues through to the end of Byzantium in 1453 and beyond. Insofar as evidence permits us to speak about the places in which this material was composed and written down, it seems that the westernruled states surviving from the Crusades on Greek lands were at least as fertile ground for its production as the area ruled by Byzantium, under the last dynasty of the Palaiologoi. The total volume is not large, but it covers a number of genres. We shall discuss in the conclusion of this paper the difficult question of the continuity of this tradition in Greece under Turkish rule.

These texts may be regarded for most purposes as the first preserved material of any length in Modern Greek, a language which bears much the same relationship to ancient and medieval Greek as does Italian to ancient and medieval Latin. The linguistic pressures of Byzantium are not dissimilar from the early history of many Western European language groups: the steady development of spoken Greek is hidden from us by the conservatism of writing, which made efforts to keep up the illusion that Greek had not "declined" from its great past-the classical Greek of the fifth and fourth centuries B.C. and the "Koine" Greek of the New Testament and the Septuagint version of the Old 
Testament. Nevertheless, linguistic pressure of change in popular speech was building up behind a dam of the linguistic censorship of Byzantine education. ${ }^{2}$ That dam was first seriously breached in the twelfth century by the popular poetry which is the subject of this article.

Byzantine popular poetry has not been much studied and more rarely still within a useful conceptual framework. Byzantinists may be tempted to regard it with the same contemptuous eye that can be observed among contemporary Byzantine intellectuals on the few occasions when they deign to notice poetry in popular linguistic and metrical forms. The information which may be derived from these poems about Byzantine history and society is quite considerable, but needs analysis of a rather different kind from that appropriate to legal documents or learned historians, and so tends to be discounted as unreliable. This poetic genre is also studied in the first chapters of histories of Modern Greek literature (e.g., Dimaras 1965, Vitti 1971, Politis 1973), and in introductory lectures to university courses in the same subject. In this case the dangers are obvious: it is very difficult to view these poems within a meaningful context, whether that of all Greek literature being produced at the time or the wider context of contemporary European literature.

There is even a problem now of national identification of Greeks with these first products of Modern Greek literature. There has always been some reluctance in Greece, dating from before the Revolution of 1821 which created the Modern Greek state, to accept as an integral part of the Greek heritage the culture of the Byzantine period. For the extreme nationalists, there was a tendency to speak and write in a way which minimized the gap between 1821 and ancient Greece, as if the death of Alexander the Great were one of the last significant events in Greek history before the Revolution. More progressive forces saw in Byzantium the epitome of all that was wrong in the modern Greek state, and preferred to view it as a kind of extension of Roman occupation rather than something essentially Greek (see Fletcher 1977). After all, the Byzantines called themselves Romans and reserved the word "Greek" for ancient pagans. The nature of the popular poems themselves, as we shall discover, does not help in national identification. The epic Digenis Akritas, hailed at its discovery as a Greek Roland or Cid, is ambivalent about its allegiances, since the hero has an Arab father and fights more Christians than 
Arabs. Other poems are translations or adaptations of French, or in one case Italian, originals. Worst of all, the Chronicle of the Morea is the foundation epic of a Western state on Greek soil, speaking at length of the faithlessness of the Byzantine Greeks who were the main power against which the Moreot principality had to defend itself.

Byzantine popular poetry thus has fallen outside the normal frameworks of literary understanding, being regularly ignored in discussions of European vernacular literature without finding a secure place within a Greek national context. The writers of this article, together with several other students of the genre, have recently attempted a reevaluation, trying to find ways of developing a framework for studying it and of understanding the purposes of those who chose to compose in it.

The most important element in this re-evaluation is the proposal that we should see in the popular poetry of Byzantium the written remains of a tradition of oral poetry. ${ }^{3}$ This statement must be very carefully qualified. We think it most unlikely that any of the surviving texts are the verbatim record of creative oral performances, taken down by the methodology of the "oral dictated text" (see Lord 1953 ) -though in one or two cases this possibility cannot be excluded, as will be discussed later. We believe, on the other hand, that it is almost impossible to explain many features of the language, meter, and style of this genre of poems without assuming that they derive in a fairly direct way from a language, meter, and style developed by oral poets for use in oral poetry. We would suggest, therefore, that Byzantine popular poetry was produced by means which approximate to those of conventional literature, but in a genre most of whose products were orally composed and disseminated. This genre was the only one available to poets who wished to write in a way which would be immediately intelligible to the uneducated majority of their audiences.

However, before seeking to support this proposal, it is only fair to point out how little direct evidence there is for it and how dependent it is on theoretical arguments by analogy with other oral traditions. Students of medieval Greek can only envy the vast mass of material available to scholars working in medieval French, not the least because of the opportunities it provides for defining the profession of jongleur, particularly from the direct statements made within the texts of the chansons de geste and by 
extrapolation from the practices observable there (see Duggan 1984). Greek evidence of this kind is extremely limited; perhaps the best example is the following from the Chronicle of the Morea:

If you desire to hear of the deeds of good soldiers, to learn and be instructed, perhaps you will make progress. If you know letters, start reading; if, on the other hand, you are illiterate, sit down by me and listen. And I hope, if you are sensible, that you will profit, since many of those who have come after them have made great progress because of the stories of those great men of old (lines 1349-55). ${ }^{4}$

Other minstrels' comments in this genre are little more than formalities, like the first words of Belthandros and Chrysantza:

Come, listen for a moment, all you young people. I want to tell you some very beautiful stories, a strange, most extraordinary tale (lines 1-3; Kriaras 1955, our trans.).

The pattern of narration set is that of one storyteller to an audience whose interest needs to be aroused. We have no way of checking that this pattern represents the physical reality of performance rather than a convenient narrative fiction.

Nevertheless, the singing of songs seems to be a significant feature of the life described in the songs. Digenis Akritas, for example, sings several songs to his beloved, and takes a musical instrument rather than a weapon when he sets out for adventure (Trapp 1971: Ms E 71112). Five songs are included in the long text (Ms N) of the Achilleis, and we are told that many more are sung in celebration of Achilles' first victory. ${ }^{5}$ Libistros and Rhodamne too is full of short love songs. ${ }^{6}$ In the Romance of Apollonios of Tyre the ability to improvise saves the virtue of Apollonios' daughter - though many of the details of the episode derive from the original text of which this is a translation (Wagner 1870: pp. 63-90; 11. 594-97, 601-4). Unfortunately, no Demodokos appears in any of the poems of this genre.

References within the works themselves are not much supported by external references to singers or minstrels within Byzantine society. We may begin with the fact that several 
troubadours formed part of the Fourth Crusade and remained in Frankish Greece afterwards. One may mention Raimbaud de Vaqueiras and Conon de Béthune, and a mysterious "Prince de l'Amorée" (see Longnon 1939). We have also noted two references to oral poetry professionals in the Frankish states of Greece - richly clad "juglars" at a ceremony in the court of Thebes for Guy II de la Roche in 1294 and a pair of "menestreux" sent by Thibout de Cepoys, agent of Charles de Valois, to a wedding among the Catalan mercenaries whom he was trying to use in his master's interest. ${ }^{7}$

The following list of references concerns singers in a more purely Greek cultural context. It makes no pretensions to completeness, but it is unlikely that it could be more than doubled, say, in length (cp. Beck 1971:50 and Beaton 1980:75-77). Monks during the iconoclast controversy were mocked by the associates of the loathed emperor Constantine V Kopronymos (741-45) to the sound of the kithara, presumably in verse (Vita: col. 1116). In the time of Michael III (842-67), an improvised song was used as part of a trick to capture a town (Bekker 1838:72). Next in chronological order comes the most hackneyed of these references, the complaint of Arethas of Caesarea about the "Paphlagonians" (meaning "windbags," not a geographical reference), who put together songs about the achievements of famous men and go round houses singing them for money (Kougeas 1913-14:239-40; Beaton 1980:77). John Tzetzes in the mid-twelfth century tells the same story of his own day (Leone 1968:III, 11. 218-67). Neophytos, a contemporary Cypriot hermit, heard a singer singing what sounds very like a modern folk song of exile. ${ }^{8}$ Niketas Choniates tells us of a song improvised by Andronikos Komnenos in 1185, as he tried to win over the servants of his successor who had captured him. He sang in alternation with his wife and mistress (van Dieten 1975:348). Maximos Planudes in his "Dialogue on Grammar" says that laments in fifteen-syllable verse were sung by "Ionian" women at funerals (Bachmann 1828:98). During the civil war between Andronikos II and III, Nikephoros Gregoras tells us of a journey he made through an area of terrifying ravines. Some of his company were singing of the "deeds of men" and the ravines reechoed antiphonally, in a way he found appropriate (Schopen 1829:vol. 1, 377). Gregoras later writes of the sequel of a famous dream of John VI Kantakouzenos (1347-54): a creator of songs who was present sang a prophecy (ibid., vol. 2, 
705-6; cp. Magoun 1955). A horoscope from Trebizond (1336) promises prosperity to singers in their composition to win their audience's attention, prophesying that December will bring them eloquence, and probably suggesting that they were improvisers (Lambros 1916). Further information from an unpublished treatise of Gregoras had recently been reported by A. F. van Gemert, together with a published comment by the Patriarch Philotheos Kokkinos (van Gemert and Bakker 1981-82). The conclusion to be drawn from the two passages is that at the time of writing (1353) songs of lament, accompanied by both wind and stringed instruments, could be heard every day in Constantinople. Michael Apostolis, in a letter written on the Dalmatian coast in 146667, is reminded of Cretan funeral and festival customs when he hears antiphonal singing (Noiret 1889:80).

However, even though these lists may be lengthened somewhat, it is most unlikely that they will ever be fully convincing about the existence of an oral tradition in Greek lands. The time-span covered is long, and the geographical area wide. Although the censorship of Byzantine education can be used to explain the removal of all non-learned material from Greek writing, it is an insufficient excuse to prevent a firm negative conclusion. In our search for direct signs of singers and their songs, we have found little evidence, scattered over different times, places, and kinds of song and singer. This serious deficiency demands in compensation really convincing evidence of other kinds to make the case for the existence of an oral tradition.

The first part of that case derives from a consideration of the meter which is employed in nearly all popular Byzantine poetry, and its connection with the first appearance of poems consistently written in Modern Greek. It is usually called the fifteen-syllable or dekapentasyllabos, less often the political verse (a name derived from a puzzling label given by some metrical scholars of the Byzantine period). ${ }^{9}$ The meter is sometimes called the national meter of Modern Greece, because it has dominated Greek folk-song since at least the last century of Byzantium and probably long before, and has been used by most Modern Greek poets, often for their solemn poetry on national themes. We have spoken above of a general lack of national identification among contemporary Greeks with Byzantine popular poetry. That indifference does not extend to its meter or, of course, to its language.

It is no accident that language and meter are extremely 
closely connected in the manuscript evidence available to us. The overwhelming majority of Modern Greek surviving in complete texts from the Byzantine period is in fifteen-syllable metrical form. Prose and other metrical patterns are both equally rare. It is no exaggeration to say that Modern Greek first broke the dam of linguistic censorship in this metrical form: it is logical, therefore, to examine the social and educational connotations of the form to see why it was so successful (see further M. Jeffreys 1974).

The first observation to be made is that the metrical form was used for writing at more learned levels of language well before the midtwelfth century, the date of the first Modern Greek vernacular poetry. The first dated specimens of the verse in which identification is secure were written in the year 913, a lament for the death of the emperor Leo $\mathrm{VI}$ in respectable Byzantine Greek..$^{10}$ It is interesting that the text is not purely fifteen-syllable: there are some half-lines too, which suggest that the form is not yet fully stable. Numerous attempts have been made to trace the earlier history of the verse, but none is fully convincing (summary in M. Jeffreys 1974:146ff.; see also Politis 1981, Lavagnini 1983, and Luzzatto 1983). This metrical shape, for example, is certainly common among the multifarious rhythmical patterns of the hymn called the kontakion (Koder 1983), but it is difficult to say whether any conclusion-even the most tentative-can be based on that fact, granted the possibility of coincidence. Origins for the fifteen-syllable pattern have been suggested in a variety of different periods and in Latin as well as Greek tradition. It is certainly striking that the most common rhythmical form of Latin medieval verse is also a fifteen-syllable form with a reversed accent pattern (trochaic rather than iambic), and the second and third most common stress meters of medieval Latin and Greek are similarly mirror-images, with the same syllable numbers - a twelve-syllable and an eight-syllable pattern (M. Jeffreys 1974:19194).

However, for those who place emphasis on surviving texts, there exists a prima facie case that the fifteen-syllable was invented at a linguistic and educational level above that of the vernacular poems, and that it spread downwards and outwards from the social and educational center of Byzantium: from the imperial court in the tenth century to folk song in the fourteenth, when it first becomes possible to make secure predictions about the form of Greek folk song (see, e.g., Politis 1970:560-63, Koder 1972, and Baud-Bovy 1973). But to anybody with a knowledge of 
medieval society in general and of Byzantine society in particular, such a judgment is self-evidently dangerous. Byzantine culture was centralized to a most disturbing degree around the city of Constantinople and the imperial court, and the popular culture of the countryside was systematically excluded from its written records at all stages, with very few exceptions. We know of no rival metrical pattern likely to attract the ear of the illiterate or half-literate Byzantine between, say, the sixth century A.D., when linguistic changes must have completed the destruction of popular appreciation of ancient meters based on long and short syllables, and the period of demonstrable popular dominance of the fifteen-syllable in the fourteenth century (M. Jeffreys 1981). How are we to react to this gap? Should we assume that folk song ceased to exist? It is obviously preferable to test the alternative theory that the prima facie case which we mentioned above is merely one of many demonstrations of the nature of Byzantine culture and society, that evidence is preserved in the center long before the periphery, perhaps even that the culture of the countryside had to be accepted and written down at the highest social and educational levels before there was any chance of it being preserved in a peripheral, rural form. The distribution of the evidence may thus tell us nothing about the nature of the meter and its origins.

If one reads carefully the surviving examples of the verse from the tenth to the twelfth century in the different varieties of learned Byzantine Greek, one may find some support for this point of view. When, for example, the verse is used by some of the capital's most pedantic literati, there is often a disclaimer or an apology. Let John Tzetzes, the most pedantic of all, speak on their behalf, in his Theogony, a simple mythological handbook in fifteen-syllable verse addressed to the sister-in-law of Manuel Komnenos:

You want to know of the Greek and Trojan generals: anything more is redundant, full of labour and effort-both for the listeners, and still more so for the writers, particularly when they have written in playful verses. For a mind which is carrying out a great task will often grow numb, when in matters where it should win praise it seems rather to be providing faults for its detractors, who have no regard for the fact of 
oikonomia. Indeed, forbearing to write the superfluous facts of heroic genealogy in the writing of apes (?), I am putting down here clearly the most important points. The rest needs time and hexameters and, more important still, a language that will bring pleasure (496508). ${ }^{11}$

Tzetzes here connects the verse form of his handbook with slapdash, simplistic work, and feels he needs to defend himself against those who will attack his choice of medium. The word oikonomia, it becomes plain in other passages, involves a compromise between the ambition of the author and the demands for simplicity imposed by his patron (M. Jeffreys 1974:151-53).

Learned works in the fifteen-syllable form cluster largely into three groups, those connected with imperial ceremonial, education, and religion (ibid:173-76). But the more one reads them the more importance one gives to a fourth element, the vernacular and popular, represented at the same period by the first Modern Greek vernacular poems of the twelfth century. The poems connected with imperial ceremonial were designed to appeal to a large popular audience, and also to communicate, in some cases at least, with members of the imperial family who were not educated to the highest standards. ${ }^{12}$ It was easier to write intelligibly in this verse than in prose, for prose always had to conform to the rules of ancient prose stylistics. The fifteen-syllable had no ancient models, and the writer could improvise with his own choice of style and language. The poems connected with education seem to involve a good deal of rote learning: grammatical rules and even dictionaries were put into the fifteen-syllable. What metrical form could be more likely to stimulate the memory than the meter of a popular oral tradition? The religious poems are often mystical or penitential in character: in the first case the inspired words fall from the poet's lips regardless, almost, of metrical form and in the second the emphasis is on simplicity and honesty of utterance. ${ }^{13}$ It would be difficult, for example, to express penitence in polished antique hexameters. In all these cases we would suggest that the reason for the choice of the fifteen-syllable is likely to have been its status as the meter of a contemporary oral tradition of narrative songs.

Although this metrical discussion has been somewhat compressed, we hope that its general pattern has been clear. To 
sum up: the fifteen-syllable meter which has dominated Modern Greek folk song since the fourteenth century at least made its debut in the Modern Greek vernacular in the mid-twelfth century, and is the metrical form of almost all early examples of the vernacular. The origins of the verse seem to go far back into the history of Byzantium, perhaps well beyond its first appearance in the early tenth century. During its written history between the tenth and twelfth centuries, it was used by some of Byzantium's driest intellectuals. However, this choice of meter is usually imposed on them by a patron who wants the commissioned work to be comprehensible. The writers regularly complain and expect to be attacked for choosing a meter with such low educational prestige. In the majority of cases, of course, the meter is used without explicit comment about the writers' attitudes. Here the genres in which the poets write are compatible with the possibility that the meter was simultaneously used in a popular oral tradition.

The discussion is not a comfortable one for a sober historian, even the historian of literature. On the one hand, there is the complete absence of direct evidence for vernacular fifteen-syllable verse before the twelfth century and for any consistent use of the verse before the tenth century. On the other hand, we may set the determined censorship of Byzantine literature against all material regarded as below an acceptable linguistic level. But above all, there is the impossibility of a void of many centuries in verse expression with meters intelligible to the uneducated. Many Byzantine specialists would accept that the most economical solution is the assumption that oral fifteen-syllable verse existed earlier, that it inspired imitation in learned language from the tenth century onwards and more direct imitation in the vernacular from the twelfth century. Perhaps the strongest single piece of evidence is a ceremonial song of four verses from the official Byzantine ceremonial, which cannot be dated earlier than the mid-tenth century Book of Ceremonies in which it is contained, but is described there as a customary part of the ceremony. In spite of its fairly formal language, this song has struck many commentators as a rural folk song only slightly adapted for its ceremonial role. What is more, the song belongs to the genre of calendar songs for spring - the chelidonismata - which is acknowledged as constituting the strongest traditional similarity between ancient and modern Greek folklore. 
See, the sweet spring is again returning, bringing joy, health, life and well-being, valor from God to the emperors of the Romans, and God-given victory over their enemies. ${ }^{14}$

Fortunately, the hypothesis of a tradition of oral poetry in Byzantium depends much less on the general considerations about the history of its meter than on analysis of the poems themselves, to which we must now turn. Our first task is to remove from the argument two very promising groups of poems, the oldest in the tradition.

The epic, or epic-romance, of Digenis Akritas was the Byzantine poem which first caughtAlbert Lord's eye, and he devoted to it some rather inconclusive pages in The Singer of Tales (1960:207-20; cp. Lord 1954). The material is promising: six manuscripts, all showing unmistakable elements of the same story but with very large variations between them; anonymity up to the two last-written of the manuscripts, which give the names of their seventeenth-century redactors; clear references in the story to wars of the ninth and tenth centuries, and a world-view which must predate the Turkish overrunning of central Anatolia in the eleventh century; a society which is at times convincingly heroic; one or two non-Christian supernatural interventions; and the survival of the names Digenis and Akritas (more usually Akritis) in Modern Greek folk song. ${ }^{15}$ Unfortunately, the poem is nearly as disappointing to students of oral poetry as it has been to Greek nationalists, as we have seen.

Under close examination it becomes plain that four of the six manuscripts cannot be oral variants, but are the product of a purely literary attempt to combine all available material and to tell the whole story of Digenis (Trapp 1971:28-29, M. Jeffreys 1975:163-201). The remaining two, G(rottaferrata) and E(scorial), represent the two sources of that compilation text. $\mathrm{G}$ has an appearance of accuracy and organization, which is unfortunately combined with a flat, anti-poetic quality of language and style that make it difficult to read. It has learned elements which it is hard to imagine being successful in an oral performance. E, though it is not without learned features, has a freshness and directness which would appear much easier to translate into oral terms. Its textual transmission, however, is extremely untidy. Until recently, it was accepted that this untidiness was the result of dictation from oral 
performance, since some of the distortion consisted of syllables extra to the basic fifteen of the verse, a phenomenon which seemed to represent some of the performance features of contemporary Greek folk song. This idea has been attacked and probably disproved, in several recent studies, and the textual problems have been approached in more conventional and systematic ways (Karayanni 1976, Chatziyakoumis 1977, Alexiou 1979 and 1983, Beaton 1980 and 1981a).

We are left, then, with the learned and tidy $\mathrm{G}$, dated around 1300 , and the less learned and more untidy E, probably written in the second half of the fifteenth century. Much of the history of scholarship on Digenis Akritas may be seen as a contest between partisans of these two manuscripts, each claiming one version as more authentic, more original, and older than the other. Recent studies have shown that both preserve authentic early information. ${ }^{16}$ Although the texts are very different, there is enough common material to indicate that the two versions have at some stage been in close contact (e.g., M. Jeffreys 1975 and Alexiou 1982). There is still much work to do in defining the nature of that contact, ${ }^{17}$ the degree of learned influence (borrowings from written texts) in both versions, and the vexed question of a hypothetical original for both surviving versions, whether it may have been in oral or written form, whether (if written) its language level was closer to the simple but learned level of $G$ or the popular level of $E$ with its scatter of learned elements. Discussion is at present impeded by the fact that for some of the participants the ideal kind of original text and subsequent transmission, with connotations of authenticity and reliability, should be oral, while for others it should be written.

Another interesting question is the relationship of the two halves of the poem. The first half is centered on the story of Digenis' father, an Arab emir who converts to Christianity. This part of the poem has a comparatively structured plot and contains most of the references to the frontier wars of the ninth and tenth century; its tone is that of comparatively realistic historical epic. The second half of the poem, which recounts the adventures of Digenis himself, is a sequence of illconnected heroic episodes with a romantic, otherworldly atmosphere, including unexpected supernatural happenings. Digenis himself, whose heroic prowess is used to keep the peace by defeating bandits who are Christian, seems to have no relevance to the history of the Euphrates border 
of Byzantium, which was one of uninterrupted hostility and almost uninterrupted war between Christian and Moslem. He does, however, read to us like the hero of a much-told poem long held in oral tradition. A consensus appears to be forming around the idea that the creator of the whole poem took a pre-extant oral poem about the emir and appended to it an unrealistic pacifist mission, taking as its hero one who was Digenis, that is, born of the two races: "At some moment between the tenth and probably the early twelfth centuries a single gifted individual must have conceived the idea of a twice-born hero as a symbol for the rapprochement of two warring empires, and grafted it on to the traditional frontier stories of Akrites" (Beaton 1981a:21; cp. Beck 1966:137-46). This sequence of events seems to the writers of this report unlikely. The pacifist vision is noble, but apparently unparalleled during the period. We would prefer to see the story of Digenis as the original. We make the hypothesis that a hero called Digenis is more likely to have demanded an emir for a father than vice versa, and that the connection between the two halves is likely to have been based on the pre-existence of an oral poem with Digenis as its hero. We have therefore suggested a much earlier situation in which the story could have arisen (M. Jeffreys 1978).

Whatever the genesis of Digenis Akritas, it seems that its present texts, G and E, are not susceptible to the most basic method of oral poetry research, that is, to formulaic analysis. After Lord's efforts in The Singer of Tales, we may report other investigations by Beaton (1981a:12-16, 1981b), confirmed by some preliminary unpublished sampling of our own. The results are certainly not negative, but far less positive than those from later texts which we discuss below. We are convinced that Digenis Akritas, in some form, spent centuries in oral tradition, and it seems likely from evidence which we will present that that oral tradition included a high level of formulas, as well as some idiosyncratic linguistic features. It is disappointing that neither $\mathrm{G}$ nor $\mathrm{E}$ has preserved these oral features intact.

The most favored milieu in recent publications for the writing (or writing down) of both versions of Digenis Akritas is the Comnenian court of the mid-twelfth century (Oikonimides 1979, E. Jeffreys 1980)which is also the date of the first independent reference to the text. This occurs in the Ptochoprodromic poems (Hesseling and Pernot 1910), a group of satirical writings attached 
to the name of one of the greatest literati of the time, Theodoros Prodromos, in which he calls himself Ptochoprodromos, "Penniless Prodromos." In fact, this attribution is probably a contemporary fiction, since the poems use the fifteen-syllable at a vernacular language level in a strikingly different metrical way from the genuine learned fifteen-syllables of Theodoros himself (H. and N. Eideneier 1978:1-7, Hörandner 1982). The tone of the poems themselves has been compared to that of the Goliardic Archpoet. The subjects are varied and lively: the poet complains about his overbearing wife, about poverty, about the poor rewards available for learning and, in the persona of a young novice, about monastic exploitation of the monks by their abbots.

We would be surprised if there is anything from popular tradition in these subjects or their treatment. It is noticeable that the poet seems in control of the linguistic medium he is using, at one moment producing lines which are purer reflections of contemporary Greek than many of the poems which were to follow, at the next, and particularly when addressing a powerful, usually imperial, patron, he raises the language level to a respectful formality. Phrases are repeated in a way which may be formulaic, but the repetitions are much too few to constitute a system as we shall find it later. These poems seem to us the work of a court poet, who is writing to exploit the vernacular tastes of the Comnenian aristocracy (who were, after all, connected with Western noble families prominent in patronage of other vernaculars; see M. Jeffreys 1981:11011; E. Jeffreys 1980:468-72). The poet may well have been expert in the writing of learned fifteen-syllables for ceremonial purposes; here he added personal themes and vernacular Greek, imitating contemporary oral tradition from the outside without being seriously touched by any of its formal constraints. The same judgment may be made of other twelfth-century experiments in popular language-the Poem from Prison of Michael Glykas, the Spanas poem of conventional advice (though there may be more formulas here) and the Eisiterioi for Agnes of France. ${ }^{18}$

The thirteenth century seems to be barren of such material, but the fourteenth is quite rich. Much had changed in the Byzantine world since the powerful, confident days of the Comnenians. The last quarter of the twelfth century combined defeat at the hands of the Anatolian Turks with a series of civil wars. The thirteenth century opened with the capture of 
Constantinople by the Fourth Crusade, the most devastating psychological blow to Byzantium before the end of its history in 1453. The imperial throne was held by the Count of Flanders, the Marquis of Montferrat became king of Salonika, many islands and towns became the possessions of the Republic of Venice, a Burgundian noble became Duke of Athens and Thebes, and the Morea, or Peloponnese, fell under the control of knights from Champagne. The three Greek fragments of the Empire which remained-Epirus, Nicea, and Trebizond-naturally became obsessed with the past, with the inheritance of the name of Rome and of the language of Homer and of the classical period. Gone was the confidence of the mid-twelfth century, when Byzantium, like France and England, could experiment with breaking the linguistic and literary forms which linked them with the legitimacy of the past. The linguistic and cultural censorship was reimposed.

After a century of Frankish control, lands like the Morea or Crete had become societies with two parallel cultures, the native Greek and the superimposed Western forms (see Jacoby 1975 and 1979, Topping 1977). Though our sources tend to stress the legal and even cultural distinction of the two races, we may assume (and even find some evidence for) considerable interpenetration. This is, in our opinion, the best framework in which to view the first fourteenthcentury poem which we wish to discuss, the Chronicle of the Morea. We remarked ealier on its strong anti-Byzantine prejudices, remarkable in a work written in Greek, but we have no doubt that Greek was the language in which the poem was first composed, and have supported our opinion at considerable length elsewhere. ${ }^{19}$ In a multi-cultural society like the Morea, it is sterile to debate the question whether the poet was Greek, French, or of mixed race, but he must have been working under the patronage of the French nobles. For them, the whole hierarchy of Greek learning would be unknown, or meaningless. A poet whom they patronized would have to be intelligible-to them, with the knowledge of spoken Greek which many of them must have acquired, and to the Moreot population, who were to be enthused with patriotism for their young state by listening to the story of its history. The taboos of learned literature would only build barriers. We may expect, therefore, an antiByzantine document in a style and language of genuine Byzantine oral poetry, a text which reflects the Greek reality in a French state far more accurately than would be possible in a Byzantine state, with its 
inevitable censorship. This is, in fact, what we find.

The Chronicle of the Morea is a highly formulaic poem. Its earliest and best manuscript, $\mathrm{H}$ (in Copenhagen) has been fully analyzed for formulas by the use of computer techniques, and was found to have $31.7 \%$ of formulaic half-lines which were identical or varied only in a carefully defined list of insignificant ways (M. Jeffreys 1973:163-95). Allowing a rather looser definition of the formula (but no looser than is often used in formulaic studies), the percentage rises to $38.4 \%$. These figures are almost meaningless on their own; however, they acquire meaning when compared to the analysis of another poem in the same fifteen-syllable meter, though in a rather more formal language, the Alexander Poem (ed. Reichmann 1963). This work is dated certainly within the same century as the Chronicle of the Morea, perhaps closer than that. By the same definitions of the formula, the Alexander gives statistics of $9.4 \%$ and $12.8 \%$, respectively. It should be stressed that these statistics refer to what is often called "straight formula," not to "passages of the same type" (the dotted underlinings of Milman Parry's tables of repetitions) which we regard as useful in the analysis of an established oral tradition but of little use in the confirmation of the existence of that tradition. In case there is any value in cross-linguistic comparisons, it is worth reporting the results of similar studies of Old French conducted by Joseph Duggan (1966), whose methodology played an important role in fixing the parameters for our own investigations. The percentage of formulas found in the Chronicle puts it in the middle of the chansons de geste, while the Alexander is less repetitious than the romances which Duggan has used as control poems.

The kinds of repetitions found, as in most non-Homeric traditions, are rather disappointing for those who have read Parry's exciting list of Homeric formulas. The most common formulas in a published list of 63 which are repeated eight or more times are simple names of Moreot barons, given in a simple form which fills the relevant half-line. Next come some toponyms and some simple phrases and clauses like "great and small," "with the army he had with him," or "that was his name." Among the less common items on the list a more prominent place is taken by verbal phrases: "and he said to him," "he informed them," and "they rejoiced greatly" (M. Jeffreys 1973:178-81). Most of the phrases have little more to recommend them as formulas than the mere fact of repetition: they are simple ideas expressed in straightforward 
language. Chief among the small number of exceptions to this rule are a few frequent formulas, most of them found also in other fourteenthcentury texts, which are expressed in grammatical and syntactical forms notably more archaic than the main body of the text. Some of them, curiously, have survived as fossilized archaic phrases into modern spoken Greek. A certain amount of dissension has grown up around these. Mohay (1974-75) and H. Eideneier (1982) regard them as proof of archaic influence on this genre of texts. We prefer to see in them some sign of the length of the oral tradition with which the poems are connected, and its importance in the history of the development of the modern language.

This strongly positive evidence must be supplemented by discussion of other tests regularly made of oral and oral-influenced poetry (M. Jeffreys 1973:195). The Chronicle is anonymous. A large proportion of its lines are end-stopped, and enjambement within the phrase or clause is rare. There are some signs of marked pauses for a performer to take a rest at fairly regular intervals. We have already seen that the poet's avowed purpose is to tell the stories of the heroes of the Fourth Crusade, especially those prominent in the conquest and organization of the Moreot principality. Since the date usually set for the composition of the Chronicle is in the 1320's, none of the events described in detail is more than 130 years old. However, the Chronicle is full of errors of fact which may be detected by comparing it with other, conventional historical sources, while it retains an easy familiarity with several aspects of Moreot life which other sources ignore-particularly those connected with the feudal organization of the principality. It seems very likely that it was based largely on oral sources (Jacoby 1968:18283, M. Jeffreys 1975b:325-26).

On the other hand, an almost negative report must be given about elements of oral organization longer than the formula, that is, the motifs and themes which loom so large in discussions of Homeric oral poetry and several medieval traditions. The parallelism of wording used at the deaths of the Chronicle's main characters approaches the status of a theme (lines 2441-67, 2752-57, 7213-39, 7753-810). Equally, there is considerable parallelism in structure between two major scenes between noble captives and their captors, that of the Moreot prince William II (lines 4092-191), and that of the Byzantine Megas Domestikos (lines 5466-575). There are subtle contrasts here redounding to 
the credit of the Moreot leader; they could be regarded as straightforward literary parallelism or as the sophisticated use of an oral thematic pattern. But it is clear that these features are exceptions and not the rule. The poem is not regularly organized by thematic structures, and as such seems to diverge from the products of several other medieval oral traditions. This fact must be given due weight in discussion of the nature of oral influence on the text.

Equally, the text which survives (we use ms H, which is the oldest and clearly the best) describes itself regularly as a book and the poet refers to his own activity as writing. There are in fact pairs of formulas which can be used with either the specific "write" or with the ambiguous "tell," which could as well refer to reading aloud or pure oral narration: "the one I tell you"/"the one I write for you," for example, or "I am telling you the truth"/"I am writing you the truth." Even cross-references take on formulaic form: the pair "Earlier in my book"/ "Later in my book" are used a total of six times. ${ }^{20}$ This confusion is not unique to the Chronicle: in the Achilleis, which we shall speak of later, it reaches the extreme form of repeating three times the phrase, "And what tongue would be able to write in detail. . ?", ${ }^{21}$ a line which could survive only at a time of transition and could not have stood for a moment against the ordinary critical judgment appropriate to purely oral or purely written poetry.

Before pronouncing a conclusion on the status of the Chronicle, we must deal with another factor, but one where it is impossible to summarize the results of a published study because that study has not yet been written. Our preoccupation derives from the lesser-known half of the work of Milman Parry on Homer, that which has to do with Homer's language. In work which culminated in his "Studies in the Epic Technique of Oral Verse-Making. II The Homeric Language as the Language of an Oral Poetry" (1932), Parry showed that his oral theories could solve with great precision and elegance the problem of the Homeric mixture of forms, including some usually identified with the Arcado-Cyprian and Aeolic dialects, together with the Ionic which was the spoken language of the milieu in which the poems reached their preserved forms. Scholars before Parry had looked for an area in which these three dialects may all have been present at the same time, but were beginning to realize that the hexameter must have a role in the way in which the dialects were combined. 
Parry's solution, simplified to its essential mechanisms, was as follows. A poet working in an oral-formulaic tradition like the Homeric and with an inflected langage like Homeric Greek needs not only formulaic patterns of expression for one grammatical case or one verbal tense, but a flexible system which reflects the changing demands of the case and tense inflections of the language. Homeric ships, for example, tend to be "equal" in the genitive singular and "black" in the dative singular, for purely linguistic reasons: a black ship in the genitive would break the meter. This system is complex and subtle, and must have needed long practice in a young singer. But what would happen when the language changed, for one of a number of possible demographic reasons, or perhaps simply because of the passage of time? Where the new linguistic form is metrically identical, the new would gradually replace the old. But where the new form is such as to break the formula, the poets would have a difficult choice: either remake the formula from the beginning or preserve the archaism. The evidence of the Homeric language suggests that the latter course was often followed in that tradition. It was a long tradition, and in some cases the language seems to have changed twice; as a result one may find in Homer three different forms of the same case of the same noun-one the natural spoken form of the poet at the moment when the poem reached its final form, and two archaisms, preserved for metrical reasons to perform two different roles within the formulaic system and the hexameter line. This part of Parry's work has never, to our knowledge, been seriously challenged in principle.

The relevance of this parallel to Byzantine popular poetry may be established by a quotation from the most authoritative summary history of the medieval Greek language (which recommends, it must be said, a different solution to the problem from that proposed here):

The existence in early vernacular literature of so many alternative verbal forms poses problems to which at present we can give no answer. The purist forms may be eliminated as due to scholarly and literary influence. But did -oun and -ousi, -eton and -otan really coexist in living speech? They were certainly living forms in different parts of the Greek-speaking world. This brings before us the problem of the origin of the 
common spoken language of the nineteenth and twentieth centuries. Does it go back to a common spoken language of at any rate the urban population in late Byzantine times, which is reflected, however imperfectly, in the language of the early vernacular poetry? Or do these poets write in an artificial amalgam of forms belonging to different dialects, which they have heard on the lips of uneducated speakers? In other words, is their poetry a kind of incompetent attempt to imitate living speech by men whose only familiar mode of expression was the literary language? To answer a blunt 'yes' or 'no' to any of these questions would be to over-simplify the matter (Browning 1983:82).

The author uses the Chronicle of the Morea more than any other Byzantine text to show the complexity and range of the linguistic macaronism of the period. To explain the observed practice, he reminds us that the poet may well be a Hellenized Frank: "Perhaps they [the variety of forms] were genuine alternatives in the language spoken by the writer. But it is more likely that he is using a mixed language, the result rather of a lack of feeling for the language than of conscious effort to raise his style above that of everyday speech" (ibid:74). We do not find it easy to believe in this Hellenized Frenchman with a defective feeling for Greek who has left a poem which is a kind of museum of all the various Greek linguistic forms used in the Middle Ages.

The language of these poems has been of interest in the question of the history of the Greek language, the battle between supporters of the vernacular dimotiki level of the language and those of the purist katharevousa, which has only very recently been settled in favor of the former. In the years around the end of the last century Yannis Psycharis, the linguist, novelist, and passionate supporter of the dimotiki, spent many years charting the development of the language of these poems, which he thought was the oral vernacular of Byzantium at the time, the unwritten history of the dimotiki. He found that there was a real development from earlier to later, with the percentage of early forms being high in poems dated early in this genre, and later forms dominating at the end of the period in a remarkably regular way. ${ }^{22}$ His opponent Georgios Chatzidakis, from among the 
supporters of katharevousa, showed, however, that whatever Psycharis was measuring it was not the development of the spoken language. By assembling all of the other available evidence for the vernacular of the time, he was able to make a convincing case that the changes from one form to another in Psycharis' tables gave an apparent date for linguistic change far too late to reflect accurately the real development of the spoken language. Several of the forms which, according to Psycharis, increase in numbers during the fourteenth century and become dominant only towards its end, were probably already the primary, even the only, forms used in vernacular speech in some areas in the twelfth century (Chatzidakis 1892). In this statement of the linguistic problem, one last point should be made: there is no Byzantine popular poem with the specific characteristics of any Modern Greek dialect, though it is likely that some features, at least, of those dialects had developed by the fourteenth century (Browning 1983:126).

A full proof that the mixed language of these texts is an oral poetic Kunstsprache, like that of Homer, will be very arduous, and can certainly not be attempted here. It will be necessary to examine, with detailed statistics, at least a score of the linguistic variations found in these texts, updating Psycharis' tables and fitting them into a complex framework of proof. A good deal of work is also needed to establish the history of each variation from all other available evidence, following the work of Chatzidakis. The following sample is offered as a sketch of the general lines that the argument will take.

We must begin from a description of the fifteen-syllable verse, which, in contrast to the Homeric hexameter, is a rather simple meter. It is based on syllable numbers and stress accents like English metrics, unlike ancient Greek prosody. Each line is divided by an invariable break after eight syllables. Each of the resultant half-lines is regulated in accent position towards its end: in the first, a word-accent must fall on the sixth or eighth syllable (of the eight), or on both, while in the second half-line, it must fall on the sixth of the seven syllables, the fourteenth of the whole line. The remaining word accents of the line nearly all fall on even-numbered syllables, confirming the underlying iambic rhythm. Most of the exceptions, the word accents on odd-numbered syllables, fall on the first and ninth syllables of the line, making the opening two syllables of each half-line metrically unregulated (Koder 1969, vol. 1:87-94; Hörandner 1974:128-33): 


$\begin{array}{cccccccccccccccr} & \mathrm{x} & \mathrm{x} & (\mathrm{o}) & (/) & (\mathrm{o}) & / & \mathrm{o} & (/) & & & & & & & \\ \text { or } & \mathrm{x} & \mathrm{x} & (\mathrm{o}) & (/) & (\mathrm{o}) & (/) & \mathrm{o} & / & \mathrm{x} & \mathrm{x} & (\mathrm{o}) & (/) & (\mathrm{o}) & / & \mathrm{o} \\ & 1 & 2 & 3 & 4 & 5 & 6 & 7 & 8 & 9 & 10 & 11 & 12 & 13 & 14 & 15\end{array}$

A moment's examination of this table will show that one syllable, accented or not, added to the seven syllables of the second half-line will produce an acceptable first half-line, and vice versa with one syllable removed. Thus the simplest pattern of usefulness to an oral poet which one could imagine would be two noun- or verb-forms equivalent in every way except that one would have an extra syllable at the end. If the accents are in the right place, the longer form could then be used at the end of the first half-line and the shorter form at the end of the second. We should like to propose that much of the diversity of language in poems like the Chronicle of the Morea may be explained in this way, in fact that this diversity is a practical working system for composition in the fifteen-syllable.

Let us take the first of the examples of macaronism quoted from Browning's description above. Third person plural verb forms ending in unaccented -oun and -ousi are found in the Chronicle of the Morea as alternative terminations for the present indicative active and both forms of the active subjunctive. In general terms, the -ousi ending is that of ancient Greek, the -oun ending that of Modern Greek. Examples of -oun can be found in the Egyptian papyri before they peter out in the seventh century, and Byzantine grammatical treatises warn that it should be avoided. On the other hand, the -ousi ending is found in several peripheral modern dialects, particularly those of Crete and Cyprus (Browning 1983:6; cp. 1976). It is occasionally found, apparently metri causa, in folk songs from other areas.

In $\mathrm{ms} \mathrm{H}$ of the Chronicle of the Morea both these forms are used systematically. In fact, if one disregards the nature of the verb-forms concerned (whether, for example, they are indicative or subjunctive) and merely collects examples of the terminations, it is possible to find as many as 59 stems from 53 different verbs which show examples of both alternative endings, as well as many more which give examples of only one of the forms. In the case of the 59 stems, one may find 280 examples in all using -ousi and 491 
using -oun. Now the -ousi ending would fit well at the end of the first half of the line and -oun at the end of the second, and we do, in fact, find a number of phrases adapted for both halves of the line by the use of this convenient variation.

The next stage of the argument involves an attempt to show that one alternative form or the other is used in the poem partly or completely because of its metrical characteristics, like an Aeolic form in Homer. In the case that we have chosen as an example, it is obviously desirable to isolate as many as possible of the forms ending in -ousi at the end of the first half of the line, though there are other possible kinds of metrical usefulness too complex to explain and justify here. It so happens that the -ousi form, though much more restricted in its use than the -oun form, cannot be shown to be an archaism to the poet of the Chronicle. The reasons are probably two: first, that the comparatively simple and relaxed form of the fifteen-syllable leaves the poet greater scope for initiative than does the hexameter, and so allows the use of archaic forms away from the limited situations which have forced their preservation within the poet's linguistic repertoire; second, that the -ousi form may not have been seen purely as an archaism, since it may still in the fourteenth century have been in use in wider areas of the Greek world than now. ${ }^{23}$

The example chosen is of average value in the proof of the oral genesis of the linguistic mixture of these texts. Of the various sets of linguistic alternatives to be studied, it has a higher than average range of application through the linguistic usage of the Chronicle-the 59 verb stems we have mentioned. On the other hand, it is less clear than is usually the case that the alternatives studied include one which is an artificial form to the poet-presumably an archaism, preserved because of its specific metrical usefulness. There are several other verb-forms and a number of noun-patterns which would give a less ambiguous result, but would need longer discussion here. Experts in contemporary Greek folk song may respond to our example and to the whole linguistic proposal that we are making by saying that it is no new suggestion that unusual linguistic forms may be used in the fifteen-syllable for metrical reasons. We would agree, but would claim that, in the Chronicle of the Morea at least, we are not dealing with exceptions, with a minority of linguistic distortions, but rather with a complete linguistic system regularly based on the needs of the meter. For us, this is one of the firmest pieces of 
evidence that the Chronicle's language and style are those of a contemporary system of oral poetry.

It is time to state formal conclusions about the role of oral tradition in the genesis of the Chronicle of the Morea. We do not believe that the poem as it stands is a text dictated in performance by an oral singer. Its own insistence on its status as a book and on writing, and the confirmation of this fact in formulaic phrases, are decisive. The absence of thematic organization also seems important, indicating perhaps that the poet is dealing with material which did not come to him in poetic form. Much of Moreot history is here told from the point of view of the lawyer and the diplomat. We have an impression that the oral style is being extended in length and subject-matter beyond its usual range, which was probably more restricted to heroic narrative. The spectacular charge of Geoffrey of Karytaina at the battle of Pelagonia (lines 401872), containing two of the very few images found in the whole poem, seems likely to reflect a short oral song of a type more conventional for the tradition.

Yet we regard this poem as a more genuine reflection of Greek oral style than any other we have examined. The evidence of the formulaic level (whether the formulas are oral formulas or specially created for the writing of this text in formulaic style) combined with the linguistic evidence is enough to convince us that oral narrative poems with similar characteristics could be heard in the thirteenth- and fourteenth-century Morea. We are also confident that, after removing some Franco-Greek language and a good deal of anti-Byzantine sentiment, it is possible to see this poem as a good reflection, perhaps the best we have, of the oral material which lies behind the whole genre of Byzantine popular poetry. There exists a later, less authentic text of the same kind as in the Chronicle, giving the history of the Italian Tocco family and their conquests in the Ionian Islands and Western Greece (ed. Schirò 1975; see also Koder 1982 and Zachariadou 1983). We have already mentioned the paradoxical judgment that Byzantine popular forms can be seen in undistorted form only in circumstances which sweep aside the rest of Byzantine culture, for otherwise the recording of genuine popular material is usually blocked.

Similar judgments can be made about much of the remainder of the fourteenth-century material in this genre, especially the romances. There are about a dozen poems which fall within the category of romance, some of them very long and preserved in 
numbers of manuscripts. Together they make up a considerable proportion of the manuscript remains of popular poetry of the period. They are divided approximately equally between poems which are translations from sources in Western European literature and those which seem to be Greek, or at least for which no western originals have been found. The question of national identification again causes problems of critical approach. The romance is to some extent a Greek genre, in spite of its name: the earliest surviving examples are the novels of Chariton, Achilles Tatios, Longus, and Heliodoros from the second to the fourth centuries A.D. (survey in Hägg 1983). Then, after a long break, there appear four more romances in the twelfth century, in the learned language, those of Theodoros Prodromos, Konstantinos Manasses (in fifteen-syllable verse), Niketas Eugenianos and Eustanthios Makrembolites (see H. Hunger 1978, vol. 2:119-42). This resurgence of the romance must be in some way connected with the simultaneous flowering of romance in the west (the direction of influence is not clear; see E. Jeffreys 1980), but the works themselves are almost pure products of the Greek tradition. However, the greatest problems of critical approach are caused by the fact that several of the fourteenth-century translations are of originally Greek material-the French Roman de Troie, the Latin Apollonios of Tyre, and Boccaccio's Theseid.

The disconcerting feature is that it is the translations, ${ }^{24}$ particularly the distorted Homeric material in the War of Troy, the French Imberios and Margarona (Pierre de Provence et la belle Maguelonne) and the Italian Florios and Platzia-Flora (Fiorio e Biancifiore), which produce, in our opinion, the best reflection of the Greek oral style. The poems which are not translations include the Alexander poem, which we have already seen used as a half-learned and non-formulaic contrast to the Chronicle of the Morea, and Kallimachos and Chrysorrhoe, possibly ascribed to a relative of the emperor Andronikos II and written without many formulas in a language rather more correct than that of the oral tradition. Belthandros and Chrysantza and Libistros and Rhodamne give a similar impression, but are somewhat closer to the oral pattern, in both formulas and language level. Only with the Achilleis and the Trojan poem edited as a Byzantine Iliad (ed. Norgaard and Smith 1975) do the original Greek works reach the same impression of oral authenticity as the translated romances mentioned above. 
These romances and the relationships between them have caused a good deal of scholarly disagreement in recent publications (survey in E. and M. Jeffreys 1983). There are numerous similarities in wording between them. At one end of the scale, these include formulaic phrases like "great and small," which is found repeated, sometimes many times, in nearly every poem of this genre. At the other end of the scale there are similarities which resemble the sudden appearance of a repeated oral theme between two poems, which is most surprising in a genre where repeated themes are rare. In one particular case, a striking phrase from Florios and Platzia-Flora, which appears to be a direct translation of the equivalent phrase in that poem's original, Fiorio e Biancifiore, is taken over into Imberios and Margarona. ${ }^{25}$

Basing himself on a solid core of evidence like this last example, and combining it with long lists of less surprising repetitions (1976, 1977-78, 1977, 1979; in addition to 1975), Guiseppe Spadaro has built up an extensive and patient case in favor of systematic plagiarism among all the poets of this genre: "E' evidente, infatti, che i poeti della letteratura greca medievale in lingua volgare si sentivano legati da uno stesso indirizzo poetico, appartenevano ad una stessa scuola poetica, per così dire, e quindi subivano, ovviamente, il fascino delle opere precedenti, alle quali spesso si ispiravano e dalle quali attingevano . . . oltre che motivi, emistichi, versi interi, insomma tutto quel formulario che all'occorrenza utilizzavano con molta comodità e grande vantaggio, sebbene a scapito dell'originalità" (1978:9). This is a school of poets who read and copy each other's work in a purely literary way. From Spadaro's tables of similarities it is possible to construct a complex network of influences among most of the poems we have mentioned in this article.

We have explained at length elsewhere why we are unable to accept this account of the way these poets worked (E. and M. Jeffreys 1983). In the first place, it does not allow enough for the influence of the copyists of our surviving manuscripts, as we shall see below. Further, Spadaro's arguments seem designed to show that similarities between the poems are not the result of chance, a position which no scholar in this field would wish to challenge. But his position is exposed to criticism on the opposite flank: he does little to prove that the phrases he collects are literary influences rather than oral formulas from a tradition known to all the poets. Spadaro concentrates attention on phrases repeated from 
one text to another, often ignoring internal repetition within the individual text, and so understating the repetitious nature of the poetry as a whole. He also does not compare each of the poems of the tradition systematically with all of the others. If he were to do so, he could find many sure examples of influence at least as convincing as some of those which he has published. The complex network of interrelationships which he implies would then become even denser and more bewildering. We find the parallel phrases he cites, in most cases, unlikely to stimulate the memory in a literary way, and prefer to ascribe their repetition to the mechanical processes associated with oral-formulaic style. Finally, the plagiarism which he suggests assumes the existence of considerable numbers of manuscript copies, so that each poet could read, and be influenced by, the work of nearly all his predecessors. However, a recent study by Manolis Chatziyakoumis (1977:247-48) has suggested that manuscripts were comparatively rare until around the year 1500, when all the poems dealt with here had long been composed.

Spadaro's work is a useful counterbalance to those who might feel that the hypothesis of the influence of an oral tradition prevents any further investigation of links between the texts under discussion. It is plain that connections can be established in several cases among those texts he examines, whether they result from common authorship, similar circumstances of composition, or even the conventional literary influence which Spadaro assumes (espec. 1975:307-9). One of these cases of similarity has recently been investigated with great care by A. van Gemert (1981), who ascribes many of the connections to the intervention of two scribes rather than to links between the original versions of the poems. As we shall see later when dealing with the textual traditions, it is vital to examine common lines for the possibility of scribal intervention. Van Gemert's article is a good example of the large volume of work which needs to be done.

Chronicles and romances do not exhaust the genres of popular poetry in the fourteenth and early fifteenth centuries, though they are far the most impressive in bulk and seem to us more relevant than any others to the discussion of oral influence. There seems no point in listing the other, less relevant genres, since Beck's handbook does this most efficiently. However, before passing from the texts themselves to their manuscript traditions, there are two other comments to make about texts which have not yet been 
mentioned.

The first is the Belisarios poem. This work has a historical basis in the story of Justinian's famous general, and is certainly not without romantic elements. Beck, however, categorizes it as a didactic poem with a moral purpose, and that seems the best way to describe the apparent motives of the surviving versions. In contrast to most of the popular romances, Belisarios is pre-eminently a poem of the populace of Constantinople. It knows a good deal of the topography of the city and is less and less convincing the further away it goes from the capital. It knows very little of Belisarios' real story, but seems to project onto this great name episodes from the lives of many popular heroes of the city, from the fifth century (a hundred years before the historical Belisarios) to the fourteenth century (when the first surviving version of the story seems to have been written). It is also one of a handful of surviving Byzantine texts which show a clear bias for the common people and against the nobility, whose role it is to poison the emperor's mind against the great popular hero. The message is a tract about the power of envy, the envy of the aristocrats for Belisarios. The whole gives the impression of being an urban folk song, expressing in one composite story the feelings of a thousand years of the capital's inhabitants for their heroes. From the point of view of formulas and language the text seems to have considerable oral characteristics, and it is tightly involved in Spadaro's tables of influences (see also van Gemert 1975).

A rather peripheral position in this discussion must be taken by a number of beast fables in fifteen-syllable verse, of which two have been analyzed in some detail by Hans Eideneier (1982:301-6) for oral influence, particularly for formulaic patterning. These poems are structured, as Eideneier says, not only by the pattern of speech and counterspeech, but also by schematic patterns of abuse and selfencomium. Perhaps as a result, there are few repetitions which fill the complete half-line, and so fulfill the formal requirements of a formula as defined in our work on the Chronicle of the Morea. Eideneier's various techniques of analysis do not depend on full half-line correspondence, and he succeeds in describing several patterns of linguistic usage which provide some support for a theory of oral influence, at least that the poems were conceived for oral presentation.

The twelfth-century examples of fifteen-syllable verse in the vernacular were court poems written by learned men outside the 
range of influence of the oral tradition which we think provoked them. Most of the fourteenth- and fifteenth-century poems were quite different. The poets, in general, seem to be away from the influence of Byzantine learning, particularly when we consider the Frankish propaganda of the Chronicle of the Morea and some of the translations from western European texts. In the latter case, for example in the War of Troy, it is very instructive to compare the Greek text with its French original. ${ }^{26}$ The Greek text has a high formulaic content (our samples give $29.3 \%$ and $35 \%$ compared with $31.7 \%$ and $38.4 \%$ for the different levels of repetition defined above for the Chronicle of the Morea). The French too is formulaic, but at a lower level of frequency. Sometimes Greek formulas seem to be made up in translation to reflect the French formulas; sometimes they are introduced by the Greek translator and one may assume, especially if they are phrases found in other poems, that they are Greek oral formulas. There is a large intermediate group of related phrases about which one cannot pronounce (E. and M. Jeffreys 1979:131-36).

All these poets, to our mind, were writing in the only style available to them which would make for easy communication in circumstances where the learned languages of Byzantium had lost their hold on published literature. The meter, the formulaic phrases, and the language mixture were all parts of the style which would be unquestioned by any writer who was accustomed to listening to Byzantine oral poetry. Whether any of those whose writings have been preserved for us also had singing skills, we can only speculate. If it turns out, as we suspect, that the language of the oral tradition is particularly closely reflected in the Chronicle of the Morea, then it could be suggested that the poet who wrote that book also performed parts of it as creative oral poems to the French and Greek inhabitants of the Moreot castle where he lived, even before he wrote them down as a text.

It is a cliché for all those who write about oral poetry that such poems do not have fixed texts, that they exist in some kind of inchoate form realized from time to time in performances which usually differ from each other, sometimes significantly. This argument may, of course, work in reverse: if a poem is preserved in several manuscripts which differ from each other in significant respects, then it is tempting to conclude that each manuscript is a separate realization of an oral Gestalt, that each somehow reflects a separate performance of the oral material. Those Byzantine poems 
which are preserved in more than one manuscript regularly show changes, great and small, from one manuscript version to another. Therefore the question has been raised whether each manuscript is a separate recording of a different realization of the same oral material. In fact, a history of this period of Greek literature (Trypanis 1981) has been written from that point of view.

On this issue we should like to sound a note of caution, with the firmness of those who have been converted to a conservative viewpoint by long and hard experience. We have been involved (with Manolis Papathomopoulos) in the edition of the War of Troy, the longest of the popular Byzantine texts, which also survives in five manuscripts and two substantial fragments, all of which show considerable variations from each other. Our initial approach to this substantial task assumed that we were unlikely to be able to print a single critical text based on all the manuscripts, and that our methodology was likely to have far more to do with Lord than with Lachmann. After 14,000 lines of editing and interminable discussions, this assumption has been totally abandoned. It seems to us that in this text the classical methodology of textual criticism is the correct way to reconstruct the original translation: both this judgement, and the reconstruction itself, are much more secure because of the survival of the French original, which often puts the critic in the position of being certain as to which of two alternative readings was found in the original text of the translation. ${ }^{27}$

Questions of oral poetry, however, are certainly not irrelevant to the reconstruction of the text within this overall logical framework. Some of the "errors" which are met represent the replacement of one formulaic line or half-line by another, and so seem rather gross to those who are used to textual transmission in which oral tradition has played no part. Furthermore, it is difficult to escape the conclusion that the existence of an oral tradition is also responsible for the number of "errors" found in the manuscripts. We are here in a totally different world from that of Lord's Yugoslavia, where the fixed, printed text tends to impose on oral poets, when they learn to read, the corrupting idea of the fixed text: "If one looks at the surviving manuscripts of the War of Troy ... it is most unlikely that they could ever have imposed upon their readers the concept of a stable text. The appearance of the page naturally varies greatly. There is no standardization of orthography so that the spelling fluctuates alarmingly in almost 
every word. Worse still . . there is no accuracy in the presentation of the words and grammatical forms of the text. In our opinion, this is not a case of literacy imposing its rigid standards upon a fluctuating oral tradition, but the reverse. The fluidity of the tradition has been carried over into its written expression, probably because the writers of the manuscripts recognized an oral style which did not demand word-forword reproduction" (E. and M. Jeffreys 1979:124). In our opinion there is a decisive difference between the world of Avdo Medjedović in the Montenegro of the 1930's and that of the War of Troy, a difference that renders invalid the cultural parallelism on which the extension of the oral-formulaic theories into the medieval period was first based. That difference is largely centered on the invention of printing. Printing changed fundamentally the relationship between one copy of a text and all other copies: only after that, it seems to us, would a text be likely to change in a singer's mind the relationship between one version of his song and all other versions.

Let us return to the War of Troy and describe its textual tradition, explaining why we regard it as basically a conventional literary tradition with only subsidiary influence from oral poetry. In the first place, the variants in the texts, although very numerous, seldom extend beyond the individual line. Our line concordance of the manuscripts very rarely shows that all extant manuscripts agree over the precise form of any one line (let alone the right way of spelling it). Variations of detail are so constant that one is forced to conclude that word-for-word accuracy was not one of the copyists' goals. On the other hand, it is equally rare for the concordance to show inserted lines, expansion or contraction of episodes, or the replacement of one episode by another. Our impression is that the copyist would read a passage of perhaps one to six lines, and would then write it out in a very similar form, with the same number of lines and similar vocabulary. In all other respects, however, he can have had no conscious policy of checking the precise form of his model: inessential words would vary, articles would be inserted or omitted, the word order would change, and a different choice would be made among the linguistic variations permitted by the mixed language.

The constant change would not be purposeful. Recognizing the language and form of a fluid oral tradition, the copyist would 
merely relax his standards of accuracy. In fact, in the whole of Byzantine popular poetry there are only one or two cases of accurate copies by the conventional definition. The relaxation would be assisted by the flexibility of the fifteen-syllable line, which must have offered the poet-in oral or written expression-greater scope for small-scale initiatives than, say, the Homeric hexameter. The whole orally-based system-meter, formulas, and language-was extremely flexible, and this flexibility was dominant enough to overcome the demands for precision usually associated with the act of copying. It is interesting that several of the manuscript variants are written in hands which betray the practiced scribe. Several identifications are being investigated, and it seems to be only a matter of time before we are able to compare the practice of the same scribe writing both learned and popular material.

There have been a number of detailed studies attempting to show the influence of scribes in causing apparent verbal echoes from one text to another. Several of these have concentrated on a 60-line interpolation at the end of ms N of the Achilleis (Michaelidis 1971-72; Spadaro 1977$78: 252,267-78)$, the connection of which to more than one other text has been hotly debated. The researches of H. Schreiner (e.g., 1966) into the relationships between the various texts always allowed for the influence of the copyist, while those of G. Spadaro (1975:313, note 5) do not do so systematically, leaving some of his results open to objection. This last point has been recently made in van Gemert's article (1981-82:95) on the relationship between the Achilleis and Belisarios. He makes great progress in the analysis of the textual transmission of both poems and in defining the nature of the phrases that they have in common, suggesting several cases which are probably due to the intervention of copyists. His results in the comparison of these two texts demand caution from all those who look for similarities between poems in this tradition-whether we are able to prove that the poems concerned have been copied by the same scribe, or whether we must merely remember to leave that hypothesis open as a possibility.

Ultimately the choice of editorial methodology in the publication of an individual text must depend on the relationships observed between or among its surviving manuscripts. Van Gemert's analysis of the Achilleis and Belisarios is, in conventional critical terms, attempting to construct a stemma codicum by 
finding common errors. We too, after some initial reluctance, have constructed a detailed stemma for the War of Troy and tested it rigorously in establishing a text of over 14,000 lines. Our testing will have been more searching than that possible in most textual traditions, because the results of our stemmatic reconstruction of the archetypal translation, more often than not, can be confirmed or denied by reference to the French original. Our stemma works in the overwhelming majority of cases of serious variants, and the few apparent contradictions can be explained by a coincidence in choice of alternative formulas, a phenomenon which is not surprising in a transmission dominated by an oral tradition. Unfortunately, the stemma does not permit the easy reconstruction of the details of the text: in nearly every line there are tiny linguistic variants too insignificant, in a fluid tradition like this, to be solved by stemmatic means, especially in the not infrequent cases where every preserved manuscript has a slightly different variant. But the general conclusion seems to us certain. In spite of the formulaic density of this text, to which we referred above, its surviving witnesses lead us back by a written tradition to a single, written translation from its French original. The oral tradition intervenes only to relax the definition of accurate copying aimed at by the scribes.

Before leaving the subject of textual tradition, it is necessary to mention two obvious cases where differences between versions of a poem are considerably greater than those described above for the War of Troy, and there is some greater chance at least of the redaction being due to a more direct form of oral intervention. The first example, of course, is Digenis Akritas in its two earlier versions of $\mathrm{G}$ and $\mathrm{E}$, described above. One may add the different versions of the Achilleis, with their very different lengths. ${ }^{28}$ Each of these examples is based on manuscripts containing other popular material, which also shows some signs of the same textual distortion. The Escorial manuscript, $\Psi$, IV 22, which contains Digenis, also includes Libistros and Rhodamne and the bird-fable, the Poulologos. The Oxford manuscript, Misc.Gr.2827, which contains the Achilleis, also has a version of Imberios and Margarona; there is also the London manuscript, BL Add. 8241, which gives the Achilleis and Florios and Platzia-Flora. We fear, however, that a detailed examination of these cases will show not oral variants but a systematic popularizing of the poems and purification from their learned linguistic elements, as we shall see 
later in the proposals of Chatziyakoumis (1977:247).

$* \quad * \quad *$

Thus in some Byzantine century before the tenth, possibly as early as the sixth, a tradition of oral poetry arose, based on the stress accent which had replaced long and short syllables as the basis of Greek metrics. The dominant rhythm came to be the fifteen-syllable. Tradition and meter gave only the most indirect signs of their existence before the tenth century, when the meter appears in the learned language. From then until the twelfth century, it was used by learned men, but for specific purposes and often with disclaimers which indicate its status as a meter below literary contempt. In the twelfth century it appears for the first time in the vernacular, but the writers are still mainly learned men and there is little direct reflection of oral style.

In the fourteenth century we are able to follow for the first time long texts which must have a real resemblance in language and style to the oral material which had been circulating for at least four centuries. The style is formulaic, and the language shows the historical depth of the tradition which had forged it. It is disappointing, though far from unexpected in Byzantine conditions, that the chronicles and romances which best reflect the oral style are non-Byzantine or even anti-Byzantine in ideology. This is not the only moment in Greek literary history when the true direction of Hellenism has been best appreciated, even exploited, by non-Hellenes, or at least by those outside the range of a Greek classical education.

It remains to say something about the continuation of the tradition up to and beyond the end of Byzantium. A key contribution here is that of Manolis Chatziyakoumis, who has examined the date, provenance, and present place of preservation of the manuscripts of Byzantine popular poetry (1977, espec. on Libistros, Kallimachos, and Belthandros). He is struck by the fact that most surviving manuscripts may be dated around the year 1500, that most are now in western European libraries, and that some at least seem to have been written in the West. He suggests that we should test the hypothesis that many may have been written by educated Greek refugees in the West after the fall of Constantinople, often in a language more uniformly popular than the mixed form in which the original texts were written, as we may see from the comparatively few older surviving manuscripts. It remains to be seen whether there is any statistical significance in 
the number of manuscripts preserved in the West, in view of the large proportion of Greek manuscripts of all periods which have found their way to the same libraries. However, if this fact is enough to make at least a prima facie case for the writing of many of these manuscripts in the West, then it is interesting to seek a way to include this new hypothesis in an overall picture of the preservation of oral material. One could surmise, for example, that the oral-based material in the West, say in Italy-and even the texts of very limited oral pedigree to which we are referring-was written down because the writers felt that they had lost contact with the tradition. As Lord has documented in Yugoslavia (1960:155-56), those living in the range of a lively oral tradition feel no need to write, since the tradition itself seems immortal. However, one could surmise that a Greek refugee in Italy after 1453 might feel the need to preserve some sign of the oral tradition he had left behind, and could have been stimulated to make a copy of a written text in the style and language of that tradition.

The final point to be made has to do with the apparent disjuncture between the poems we have been studying and most of the poems of Modern Greek folk song. So far as we are able to observe the latter, through scattered texts from the Turkish period up to the eighteenth century, through earnest nineteenth-century collecting, and through systematic study of the twentieth-century remains, we must conclude that Modern Greek folk songs tend to be short and lyrical, rather than long and narrative like the poems spawned by the medieval tradition. At first sight, we can only assume that the one tradition must have died so that its successor could take over. On a more careful examination, however, there appears a more conservative branch of the modern tradition, with narrative songs in Crete and particularly in Cyprus, which can be compared directly with the medieval poems. On this point we may await the enlightenment of Roderick Beaton, who has made a special study of the Cypriot tradition. ${ }^{29}$

University of Sydney

Notes

${ }^{1}$ The handbook of H.-G. Beck (1971) gives a comprehensive survey and 
full bibliography through 1971 of the texts discussed here, and should be consulted for the older literature on the subject. For work between 1971 and 1978, see E. Jeffreys 1979 and 1981, Beaton 1980 (espec. 7-86), Eideneier 1982-83. See also the general discussion in M. Jeffreys 1975a.

${ }^{2}$ The most accessible history of the Greek language is Browning 1983; see also Browning 1978.

${ }^{3}$ This proposal stems from Trypanis (1963), who has put the idea into practice, with wider claims than we would dare to support, in Trypanis 1981.

${ }^{4}$ Schmitt 1904; there exists a translation by Lurier (1964).

${ }^{5}$ Ms. N 272-77, 970-84, 1223-29, 1290-94, 1540-46 (Hesseling 1919).

${ }^{6}$ E.g., E 1541, 1735, 1906 (Lambert 1935).

${ }^{7}$ Lanz 1844:par. ccxliv. On Thibaut de Cepoys, see du Cange 1657:vol. 2, 355.

${ }^{8}$ Partially ed. in Tsiknopoulos 1952; see M. Jeffreys 1974.

${ }^{9}$ E.g., Eustathios of Thessalonika, in van der Valk 1971:vol. 1:19; trans. in M. Jeffreys 1974:147.

${ }^{10}$ Ševčenko 1969-70:185-228.

${ }^{11}$ Trans from John Tzetzes, Theogonia (Bekker 1840:147-69).

${ }^{12}$ E.g., the empress Eirene, formerly Bertha von Sulzbach, first wife of the emperor Manuel Komnenos; and the sebastokratorissa Eirene, widow of Manuel's older brother. The one was certainly and the other probably of Western origins, and both were dedicatees of simple introductions to aspects of Greek classical culture.

${ }^{13}$ Mystical: e.g., Symeon the New Theologian (Koder 1969 and Kambylis 1976); Penitential: e.g., Nikephoros Ouranos (Papadapoulos-Kerameus 1899).

${ }^{14}$ Constantine Porphyrogennetos, Le Livre des cérémonies (Vogt 1967:vol. 2, chap. 82, pp. 165, 167). For discussions, see Baud-Bovy 1946.

${ }^{15}$ The voluminous older literature is conveniently available in Beck 1971:63-97.

${ }^{16}$ For Ms. E, Alexiou 1979:33-35; for Ms. G, Oikonomides 1979.

${ }^{17}$ An interesting argument is advanced in Macallister 1984.

${ }^{18}$ For editions of Glykas and the Spaneas poem, see Beck 1971:101-9; the "Eisitirioi" for Agnes of France are edited in Stryzygowski 1901.

${ }^{19}$ M. Jeffreys 1975b. Different views can be found in Jacoby 1968:187-88, 1976; Spadaro 1959, 1960, 1961.

${ }^{20}$ Chronicle of the Morea 3179, 3469, 4683, 4885, 6249, 7556.

${ }^{21}$ Achilleis, Ms. N 69, 96, 778.

${ }^{22}$ The material is most completely available in Psicharis 1886-89.

${ }^{23}$ Tables and lists of examples to support these statements are given in M. Jeffreys

1972.

${ }^{24}$ For details of editions, see Beck 1971.

${ }^{25}$ See the discussion and bibliographical details given in Spadaro 1975 
(espec. 309)

${ }^{26}$ Given the continued delays in the appearance of the edition, see the examples given in E. and M. Jeffreys 1979.

${ }^{27} \mathrm{On}$ the manuscripts and their relationships, see the preliminary (but still accurate) statement in E. Jeffreys 1976.

${ }^{28}$ Ms. M: 1820 lines; Ms. L: 1363 lines; Ms. O: 761 lines.

${ }^{29} \mathrm{~A}$ first example is provided in Beaton 1980:162-68, 174-78. See also his essay in an earlier issue of Oral Tradition (1986).

The two writers of this article have invested more of their research labors than anyone else they can name in attempts to solve the problems of Byzantine popular poetry, trying to develop comprehensive methods of analysis from among the range of interests covered by Oral Tradition. Thus it has proved impossible to carry through an impersonal and objective survey: it has seemed more honest to present our views clearly, while explaining others' objections and alternative proposals, and scrupulously noting all bibliography of which we are aware. We hope to have avoided narcissism in referring to our own writings, but such references remain uncomfortably frequent. Only the reader may judge if the result is of any use.

\section{References}

Alexiou 1979

S. Alexiou. Akritika. Iraklio: Alexiou.

Alexiou 1982

"Paratirisis ston Akriti” Ariadni, 1:41-57.

Alexiou 1983

."O Digenis Akritas tou Escorial." Praktika tis Akadimias Athinon, $58: 68-83$

Bachmann 1828

L. Bachmann. Anecdota Graeca. Leipzig. Rpt. Hildesheim: Georg Olms, 1965.

Baud-Bovy 1946

S. Baud-Bovy. "Sur le chelidonisma." Byzantina-Meta-byzantina, 1:23-32.

Baud-Bovy 1973

Ellinika, 26:301-13.

Beaton 1980

Roderick Beaton. Folk Poetry of Modern Greece. Cambridge: Cambridge University Press.

Beaton 1981a

Studies, 7:7-27.

"Was Digenis Akritas an Oral Poem?" Byzantine and Modern Greek

Beaton 1981b

. "Digenis Akritas' and Modern Greek Folk Song: A Reassessment."

Byzantion, 51:22-43. 
Beaton 1986

$$
1: 110-33
$$

"The Oral Traditions of Modern Greece: A Survey." Oral Tradition,

Beck 1966

H.-G. Beck. "Formproblem des Akritas-epos." In his Beiträge zur Südosteuropaforschung. Munich: C. H. Beck.

Beck 1971

Bekker $18 \overline{38}$ Geschichte der byzantinischen Volksliteratur. Munich: C. H. Beck.

I. Bekker, ed. [Theophanes Continuatus]. Bonn: E. Weber. Bekker 1840

Klasse:147-69.

Browning 1976

R. Browning. "Problems concerning the Genesis of Modern Greek." In XVe Congrès international des études byzantines. Athens. pp. 3-18.

Browning 1978

. "The Language of Byzantine Literature." In The "Past" in Medieval and Modern Greek Culture. Ed. S. Vryonis. Malibu: Undena. pp. 103-33.

Browning 1983 Medieval and Modern Greek. 2nd ed. Cambridge: Cambridge University

Press.

Chatzidakis 1892

G. N. Chatzidakis. Einleitung in die neugriechische Grammatik. Leipzig: von Breitkopf and Härtl.

Chatziyakoumis 1977

M. Chatziyakoumis. Ta mesaionika dimodi kimena: symvoli sti meleti ke stin ekdosi tous. Athens: Chatziyakoumis.

Dimaras 1965

D. Dimaras. Histoire de la littérature néohellénique, des origines à nos jours. Athens: Ikaros.

du Cange 1657

C. du Cange. Histoire de l'empire de Constantinople sous les empereurs françois. Paris.

Duggan 1966

Joseph J. Duggan. "Formulas in the Couronnement de Louis." Romania, 87:315-44. Duggan 1984

. "Oral Performance, Writing, and the Textual Tradition of the Medieval Epic in the Romance Languages: The Example of the Song of Roland." Parergon, n.s. 2:79-96.

H. Eideneier 1982

H. Eideneier. "Zum Stil der byzantinischen Tierdichtung." Jahrbuch der Österreichischen Byzantinistik, 32, iii:301-6.

H. Eideneier 1982-83

. "Leser- oder Hörenkreis? Zur byzantinischen Dichtung in der 
Volkssprache." Ellinika, 34:119-50.

H. and N. Eideneier 1978

and N. Eideneier. "Zum fünfzehnsilber der Ptochoprodromika." In

Aphieroma ston kathigiti Lino Politi. Thessaloniki. pp. 1-7.

Fletcher 1977

R. A. Fletcher. "Cultural and Intellectual Development 1821-1911." In Greece in Transition: Essays in the History of Modern Greece 1821-1984. Ed. S. Koumoulides. Hhgg 1983

London: Zeno. pp. 153-72.

Hesseling 1919

T. Hägg. The Novel in Antiquity. Oxford: Blackwell.

D. C. Hesseling, ed. L'Achilléide byzantine. Verhandelingen der k. Akad. van

Wetenschapen te Amsterdam, Afd. Letterkunde, n.r. 19.3.

Hesseling and Pernot 1910

and H. Pernot, eds. Poèmes prodromiques en grec vulgaire. Verhand-

elingen der k. Akad. van Wetenschapen te Amsterdam, Afd. Letterkunde, n.r. 11.

Hörandner 1974

W. Hörandner. Theodoros Prodromos: Historische Gedichte. Wiener Byzantinistische Hörandner 1982

Studien (Österreichische Akademie der Wissenschaften), 11.

Hunger 1978

Österreichischen Byzantinistik, 32, iii:375-82.

H. Hunger. Die hochsprachliche profane Literatur der Byzantiner. 2 vols. Munich: Jacoby 1968

C. H. Beck.

D. Jacoby. "Quelques considérations sur les versions de la 'Chronique de Morée'."

Journal des savants [for 1968]:133-89 (=Jacoby 1975:VII). Jacoby 1975

Variorum Press.

Société et démographie à Byzance et en Romanie latine. London:

Jacoby 1976

. "Les Etats latins en Romanie: Phénomènes sociaux et économiques

(1204-1350 environ)." In XVe Congrès international des études byzantines. Athens. Jacoby 1979

pp. 1-51 (=Jacoby 1979:I).

\section{London: Variorum Press.}

E. Jeffreys 1976

Elizabeth M. Jeffreys. "The Manuscripts and Sources of the War of Troy." In Actes

du XIVe congrès international des études byzantines, 1971. Bucharest: Academiei

E. Jeffreys 1979

Republicii Socialiste Romania. pp. 91-94.

Since 1971." Mandatoforos, 14:20-34.

E. Jeffreys 1980

. "The Popular Byzantine Verse Romances of Chivalry: Work Done

"The Comnenian Background to the romans d'antiquité." 
Byzantion, 50:455-86.

E. Jeffreys 1981

"The Later Greek Verse Romances: A Survey.” In Byzantine Papers. Ed. E. M. and M. J. Jeffreys and A. Moffatt. Canberra: Humanities Research Centre, Australian National University. pp. 116-47.

E. and M. Jeffreys 1979

and Michael J. Jeffreys. "The Traditional Style of Early Greek Demotic Verse." Byzantine and Modern Greek Studies, 5:115-39 (= 1983a:III).

E. and M. Jeffreys 1983a

E. and M. Jeffreys $1983 \mathrm{~b}$

Popular Literature in Late Byzantium. London: Variorum Press. Ukrainian Studies, 7:309-43.

M. Jeffreys 1972

Michael J. Jeffreys. "Studies in the Language and Style of the Medieval Greek Chronicle of the Morea." Unpub. Ph.D. diss., London University.

M. Jeffreys 1973

"Formulas in the Chronicle of the Morea." Dumbarton Oaks Papers, 27:163-95 (= E. and M. Jeffreys 1983a:II).

M. Jeffreys 1974

. "The Nature and Origins of the Political Verse." Dumbarton Oaks

Papers, 28:142-95 (= E. and M. Jeffreys 1983a:IV).

M. Jeffreys 1975a

M. Jeffreys $1975 b$

"The Literary Emergence of Vernacular Greek." Mosaic, 8, iv:171-93. Jeffreys 1983a:V).

M. Jeffreys $1975 \mathrm{c}$

"Digenis Akritas Manuscript Z." Dodone, 4:163-201 (= E. and M.

"The Chronicle of the Morea: Priority of the Greek Version." Byzantinische Zeitschrift, 68:304-50.

M. Jeffreys 1978

. "Digenis Akritas and Kommagene." Svenska Forskningsinstitutet $i$

Istanbul Meddelanden, 3:5-28 (= E. and M. Jeffreys 1983a:Vll).

M. Jeffreys 1981a

"Byzantine Metrics: Non-literary Strata." Jahrbuch der Österreichischen

Byzantinistik, 31, i:313-34.

M. Jeffreys 1981 b

“"The Eisitirioi for Agnes of France." In Byzantine Papers. Ed. E. and M. Jeffreys and A. Moffatt. Canberra: Humanities Research Centre, Australian National University. pp. 101-15.

Kambylis 1976

A. Kambylis, ed. Hymnen. Berlin and New York: De Gruyter.

Karayanni 1976

I. Karayanni. O "Digenis Akritas" tou Escorial: Symvoli sti meleti tou kimenou. Meletes sti Nea Elliniki Philologia (University of Ioannina), 1. 
Koder 1969

J. Koder, ed. Hymnes. Sources Chrétiennes, 156. Paris: Editions du Cerf. Koder 1972

— "Der Fünfzehnsilber am Kaiserlichen Hof um das Jahr 900." Byzantinoslavica, 33:214-19.

Koder 1982

. "Die Chronik der Tocco. Zum Metrum and zum Verhältniss zur Chronik Koder 1983

von Morea." Jahrbuch der Österreichischen Byzantinistik, 32, iii:383-92.

Byzantinistik, 33:45-56.

Kougeas 1913-14

S. B. Kougeas. "E en tis scholiis tou Aretha laographike eidisis." Laographia, 4:23940.

Kriaras 1955

E. Kriaras, ed. Byzantina Ippotika Mythistorimata. Athens: Aetos. Lambert 1935

J. A. Lambert, ed. Le Roman de Libistros et Rhodamné. Verhandelingen der k. Akad. van Wetenschapen te Amsterdam, Afd. Letterkunde, n.r. 35.

Lanz 1844

K. Lanz, ed. Chronica, by Raymond Muntaner. Stuttgart: Literarischer Verein. Lambros 1916

S. Lambros. "Trapezoundiakon oroskopon tou etous 1336." Neos Ellinomnimon, $13: 33-50$.

Lavagnini 1983

B. Lavagnini. "Alle origini del verso politico." Istituto Siciliano di Studi Bizantini e Leone 1968

Neoellenici, Quaderni 11.

P. A. M. Leone, ed. Ioannes Tzetzae Historiae. Istituto di filologia classica, Longnon 1939

Publicazioni, 1. Naples: Libreria Scientifica Editrice.

Lord 1953

J. Longnon. "Le Prince de Morée chansonnier." Romania, 65:95-100.

Albert B. Lord. "Homer's Originality: Oral Dictated Texts." Transactions of the American Philological Association, 84:124-34.

Lord 1954 Studies, 2:375-83.

"Notes on Digenis Akritas and Serbo-Croatian Epic." Harvard Slavic Lord 1960

The Singer of Tales. Cambridge, MA: Harvard University Press, 1960. Lurier 1964

Rpt. New York: Atheneum, 1968 et seq.

H. E. Lurier. Crusaders as Conquerors: The Chronicle of Morea. New York: Columbia University Press. 
Luzzatto 1983

M. J. Luzzatto. "La Datazione della Collectio Augustana di Esopo ed il verso politico delle origini." Jahrbuch der Österreichischen Byzantinistik, 33:137-78.

Macallister 1984

S. Macallister. "Digenis Akritas: The First Scene with the apelatai." Byzantion, 54:551-74.

Magoun 1955

Francis P. Magoun, Jr. "Bede's Story of Caedman: The Case History of an AngloSaxon Oral Singer.” Speculum, 30:49-63.

Michaelidis 1971-72

D. Michaelidis. "Palamedes Rediens: La fortuna di Palamede nel medievo ellenico." Rivista di studi bizantini e neoellenici, n.s. 8-9 [18-19]:261-80.

Mohay 1974-75

A. Mohay. "Schriftlichkeit und Mündlichkeit in der byzantinischen Literatur." Acta Noiret 1889 Classica (Debrecen), 11:175-81.

H. Noiret. Lettres inédites de Michel Apostolis. Paris: E. Thorin.

Norgaard and Smith 1975

L. Norgaard and O. L. Smith, eds. A Byzantine Iliad. Copenhagen: Museum Tusculanum.

Oikonomides 1979

N. Oikonomides. 'L' 'Epopée' de Digenis et la frontière orientale de Byzance au Xe et XIe siècles." Travaux et mémoires, 7:375-97.

Papadopoulos-Kerameus 1899

A. Papadopoulos-Kerameus, ed. "Byzantina Analekta." Byzantinische Zeitschrift, 8:66-70.

Parry 1932

Milman Parry. "Studies in the Epic Technique of Oral Verse-Making. II The Homeric Language as the Language of an Oral Poetry." Harvard Studies in Classical Philology, 43:1-50.

Politis 1970

L. Politis. "Problèmes de la tradition du texte et des rapports avec les chansons akritiques." In Atti del convegno internazionale sul tema: La Poesia epica e la sua Politis 1973

formazione, 1969. Rome: Accademia Nazionale dei Lincei. pp. 551-81.

Press, rpt. 1975

Politis 1981

A History of Modern Greek Literature. Oxford: Oxford University

"Neoteres apopsis ya to gennesi ke ti domi tou dekapentasyllavou."

Praktika tis Akadimias Athinon, 56:209-28.

Psicharis 1886-89

J. Psicharis. Essais de grammaire historique néogrecque. 2 vols. Paris: Bouillon. Reichmann 1963

S. Reichmann, ed. Das byzantinische Alexandergedicht. Meisenheim am Glan: A. Hain. 
Schirò 1975

G. Schirò, ed. Cronaca dei Tocco di Cefalonia. Rome: Accademia Nazionale dei Lincei.

Schmitt 1904

J. Schmitt, ed. The Chronicle of the Morea. London: Methuen. Rpt. Groningen:

Bouma, 1907.

Schopen 1829

L. Schopen, ed. Nikephoros Gregoras. Bonn: E. Weber.

Schreiner 1966

H. Schreiner. "Die Einleitenden Handschriften zu den von der gleichen Hand überlieferten Texten in Cod. Neap. Gr. III Aa 9 and Co. Neap. Gr. III B 27.” In Polychordia: Festschrift F. Dölger. Heidelberg: A. Hakkert. pp. 290-320.

Ševčenko 1969-70

I. Ševčenko. "Poems on the Deaths of Leo VI and Constantine VII in the Madrid Spadaro 1959

Manuscript of Scylitzes." Dumbarton Oaks Papers, 23-24:185-228.

G. Spadaro. "Studi introduttivi alla Cronaca di Morea I." Siculorum Gymnasium, 12:125-52.

Spadaro 1960

Spadaro $1 \overline{961}$

. "Studi introduttivi . . II." Siculorum Gymnasium, 13:133-76.

Spadaro 1975

. "Studi introduttivi . . . III." Siculorum Gymnasium, 14:1-70.

Rapporti tra Imberios e Margarona e Florios e Platzia-Floria" Ellinika 28.302-37.

Spadaro 1976

. "Problemi . . II: Rapporti tra Diigisis tou Achilleos, la Diigisis tou

Velisariou e Imberios ke Margarona.” Ellinika, 29:278-310.

Spadaro 1977

Spadaro $1 \overline{977-78}$

. "Sul Teseida neogreco." Folia Neohellenica, 2:157-60.

. "Problemi ... III: Achilleide, Georgillàs, Callimaco, Beltandro, Libistro,

Florio, Imberio, e Diigisis genameni en Tria." Ellinika, 30:223-79.

Spadaro 1978

Zeitschrift, $71: 1-9$.

Spadaro 1979

Stryzygowski 1901

. "Spaneas e Glikas: Note filologiche." Diptycha, 1:282-90.

J. Stryzygowski. "Das Epithalamium des Paläologen Andronikos II." Byzantinische Topping 1977

Zeitschrift, 10:546-67.

Trapp 1971

P. Topping. Studies in Latin Greece AD 1205-1715. London: Variorum Press.

E. Trapp, ed. Digenes Akrites: Synoptische Ausgabe der ältesten 
Versionen. Wiener Byzantinische Studien (Österreichische Akademie der Wissenschaften), 8.

Trypanis 1963

C. A. Trypanis. "Byzantine Oral Poetry.” Byzantinische Zeitschrift, 56:1-3.

Trypanis 1981

Tsiknopoulos 1952 . Greek Poetry from Homer to Seferis. London: Faber.

I. P. Tsiknopoulos. "I piitiki paragogi tou englistou agiou Neophytou." Kypriake spoude, 16:41-49.

van der Valk 1971

M. van der Valk, ed. Commentarii ad Homeri Iliadem pertinentes, by Eustathios of Thessalonika. Leiden: E. J. Brill.

van Dieten 1975

I. A. van Dieten. Nicetae Choniatae Historia. Berlin and New York: De Gruyter. van Gemert 1975

A. F. van Gemert. "The New Manuscript of the History of Belisarios." Folia Neohellenica, 1:45-71.

van Gemert and Bakker 1981

$33: 82-97$

Vita

and W. F. Bakker. "I Achiliida ke i istoria tou Velisariou." Ellinika,

Vitti 1971

Vita Stephani Iunioris, Patrologia Graeca 100, col. 1116.

M. Vitti. Storia della letteratura neogreca. Letteratura e civilita, 16. Turin: Edizioni Rai Radiotelevisione Italiana.

Vogt 1967

A. Vogt, ed. Le Livre des Cérémonies, by Constantine Porphyrogennetos. 2 vols. Paris: Société d'Editions "Les Belles Lettres." Wagner 1870

W. Wagner, ed. Medieval Greek Texts. London. Rpt. Hildesheim: Gerstenberg, 1971.

Zachariadou 1983

E. Zachariadou. "I chilii stichi stin archi tou Chronikou ton Tocco." Ipirotika Chronika, 25:158-81. 